\title{
Shaping the Slovak Identity and the Manifestation Thereof in the Social Iconosphere. The Case of the Slovak National Museum*
}

\author{
DAVID VÁCLAVÍK**
}

Formování slovenské identity a jejího projevu v sociální ikonografii. Př́pad Slovenského národního muzea

\begin{abstract}
The article deals with the role of the National Museum in the process of creating a Slovak national identity. It focuses mainly on the specifics that were associated with the establishment of the Slovak National Museum as an institution. These were closely related to the complicated history of the formation of Slovak national consciousness in the 19th and 20th centuries. It also focuses on analyzing the architecture of the main buildings of the Slovak National Museum and its connection with the concept of the museum as an educational, public, and political institution. Finally, it analyzes two important permanent collections - historical and ethnographic. At the same time, attention is paid to the role played by the well-known conceptualizations of the Slovak nation.
\end{abstract}

Keywords: Slovak National Museum; national identity; discursive analysis; nationalism; religion

DOI: $10.14712 / 23363525.2019 .15$

"Where are we headed? It is not to the emptiness. The emptiness will not engulf us. We are headed to our ancestors." (Dominik Tatarka)

Almost ten years ago, a book entitled My a tí druhí v modernej spoločnosti. Konštrukcie a transformácie kolektívnych identit (Us and the Others in Modern Society. Constructions and Transformations of Collective Identities) [Kiliánová- Kowalská - Krekovičová 2009] was published in Bratislava, and I was asked to review the part concerning religion. The book deals with the issue of national identity in a very extensive and systematic manner. The authors treat the difficulties and complexities of shaping the modern Slovak nation, quite often defining itself in opposition to "the others", using various perspectives, from linguistic to sociological ones. The entire process is aptly described as mutual penetrating, searching as well as refusing, which lead to "finding" a place somewhere among "the strong others" (Hungarians, Czechs or even Germans) and "the weak others" (Roma, Jews, Ruthenians). While repeatedly reading this remarkable work, I realized that the presented studies, describing and analyzing this process of (self)construction of the modern Slovak

\footnotetext{
* The study was supported thanks to the Czech Science Foundation. The project GAČR with registration number 18-11345S is entitled Ateismus, volnomyšlenkářství a sekularizace v zemích střední a východní Evropy ve 20. a 21. století (Atheism, Freethought and Secularization in Central and Eastern European Countries in the Twentieth and Twenty-First Centuries).

** Assoc. Prof. David Václavík, Ph.D., Department for the Study of Religions, Faculty of Arts, Masaryk University, Arne Nováka 1, 60200 Brno, Czech Republic. E-mail: Vaclav@phil.muni.cz
} 
nation, lack some points to make it complete. It took me quite a long time until I found out what that was.

All the usual phenomena such as language, religion, tradition and history playing the key role in the process of shaping collective identities have been taken into account in the book. I eventually realized, primarily after reading several excellent studies dealing with so-called embodied cognition [cf. for ex. Shapiro 2011], that what I was missing was an analysis of the images and artifacts, which are used widely to construct national identities. And this not only as comprehensible illustrations of who we are, but also (and, in a certain manner, in particular) as the materialization of the multi-layer construction, which is the national and ethnic one. In other words, it is often images and artifacts, which make concepts "real" and comprehensible and persuasive at the same time.

In the meantime, an inspiring monograph entitled Náboženstvo vo verejnom živote na Slovensku (Religion in the Public Life in Slovakia) [Tižik 2011], written by a prominent Slovak sociologist of religion, Miroslav Tížik came out. From the point of view of methodology, he uses the concepts of the Polish sociologist, Piotr Sztompka, in particular his idea of visual sociology [Sztompka 2007]. Sztompka claims that visual ideas, together with visual manifestations, create the visual universe of a society, which he calls social iconosphere. The images and symbols, of which it is composed, are believed by Sztompka to be not only a relevant and independent object of cognition, but also the means to recognize something else - specifically the life of a society and the transformation thereof. A key component thereof are pictorial stereotypes often closely corresponding to their social counterparts and contributing to the constitution, preservation and transfer of these [Sztompka 2007: 10-22; cf. also Tížik 2011: 32n].

Considering the ample analysis of the role of religion in the history of Slovakia and the importance of religion when shaping the Slovak national and ethnic identity, I found most interesting the closing chapters of the book, especially that entitled Kódy a symbolika Slovenskej republiky (Codes and Symbols of the Slovak Republic). In this chapter, referring to R. Bellah's concept of civil religion [cf. for ex. Bellah 1967; Bellah 1975] and the application thereof to the Slovak environment as argued by the sociologist Silvia Miháliková [Miháliková 2005], Tížik deals with the possibility of also using "texts without words, such as names of streets, anniversaries, statues of leaders but also the iconography used on coins and banknotes" [Tižik 2011: 300n] in order to understand the construction of national identity as something being shaped using the construction of signs (e.g. using language, mythical or political narrative, etc.).

In his analysis, Tížik opted for coins and banknotes used in Slovakia from 1993 until the adoption of the Euro in 2008. His detailed study demonstrates that the schemes and symbols appearing on them correspond to the attempt of the newly created state to establish a sufficiently strong identity as well as to the need to create persuasive legitimization tools at the symbolic level. All this was found in the environment of Christian traditions, or the inception thereof linked to Great Moravia. He claims to have included several levels. First, this tends to concern the rather non-controversial "topics" of Slovak history, which were easy to identify with by the majority of Slovak society, but which are present over the long-term in the latent collective memory of Slovaks, and finally, both refer closely to what the political scientist, Andrej Findor calls the "golden era" of the Slovak nation, which is dated to the period between the arrival of the Slavs and the final 
inclusion of today's Slovakia in the Medieval Hungarian kingdom. Both Tízik and Findor point out the key role of the political and cultural elites, which usually decide using their factual and symbolic power about who or what event will be the subject of the public discourse and will be included in the virtual symbolic world implied in the daily reality we live in [Tižik 2011: 302].

As we will see further, both aforementioned concepts and symbols and artifacts linked to these play an important, in many respects even key role in "materializing" the concept of national or state identity, in particular in the National Museum. Before reaching that issue, the idea of the conceptualization of national identity and shaping of national myth needs to be addressed.

As opposed to many nations and states in Central Europe, the Slovak national identity began to be shaped as late as the second half of the nineteenth century, while the political one was not formed until the twentieth century. Up until then, the fate of Slovakia, both the political and cultural one, was very closely linked to Hungary, which was part of today's Slovak territory from the beginning of the eleventh century up until 1918. It is remarkable that in this constitutive phase of the conceptualization of Slovak national and cultural identity, topics, which will become primordial for later authors, in particular the close adherence of Slovaks to Christianity, were not topicalized. This can be seen in many topics analyzed by Tížik - be it national symbols, important places or themes of coins, banknotes or postage stamps.

One of the very interesting Slovak intellectuals who devoted himself to defining Slovak national identity was Ján Francisci (1822-1905), who, in his work Slovenske povesti (Slovak Legends) [Francisci 1845] tried to use references to Slovak folk literature and demonstrate not only the "substance of the Slovak nation", but also, and possibly in particular, support his own ideas of the nation's future [Pauza - Hajka 1989]. Francisci's interest in folk literature and the forms of religiosity thereof is thus unambiguously linked to the political concept of the Slovak nation and his analyzes of the individual topics and characters in myths and legends shared among Slovaks are of a philosophical-ideological character rather than a ethnographic one:

The newborn spirit of the Slavic people, the youngest son of humankind, is the sacred and predestined hero, who, wishing to create a world and life for himself, enters this miraculous field searching for his life-giving blood, searching and picking up elements to embody [...]. We, the Slavs, could not have yet lined up with other nations by our historic past, nor could we have believed the aspects of our specific spirit to be the drive of humanity: still, our spirit bears specific appearances, in which he can be seen and is easy to read as in a book. These appearances are our Slavic local, social, civil and religious life, art, language, science, etc. - And if we ask, what includes our prophetic and specific appearance as it is expressed and kept? - my answer is: it is included in our legends." [Francisci 1845: 8n]

Another influential figure was the Protestant theologian Ján Lajčiak (1875-1918). The work of Ján Lajčiak was "discovered" and elaborated in a way by Samuel Štefan Osuský, who posthumously published his key tract entitled Slovensko a kultúra (Slovakia and Culture) [Lajčiak 1920]. This treatise, presented as a typical example of "engaged sociology", is very valuable since it is the first one to analyze and evaluate the importance of religiosity for Slovak society and culture and demonstrate that one of the elementary aspects thereof 
is the traditionalism linked to the social pressure, and the means of which it is maintained and transferred:

A Slovak embodies his religious feelings in each moment of life, he takes religion to be the substantial component of life and nobody can deprive him of it [...]. For a Slovak, religiousness is something so very innate that he is capable of covering even a sin with a religious garment [...]. For many, the religious life is the life of pure habits. There are many who go to the temple not to learn but to comply with habits. [Lajčiak 19942: 106-108]

In contrast to some other authors (e.g. Anton Kompánek), Lajčiak was well aware that the relationship of Slovaks to religiousness may not be explained with reference to one religious tradition or institution, but that it is formed by a certain variation of religious pluralism [cf. Nešpor 2008]. He was also among the first to indicate the beginning of the process of secularization of a part of Slovak society (especially the intellectual elite), which he links to the decline of the church's prestige as an institution and to a progressive replacement of the religious explanation of the world with a scientific approach. Religion is therefore perceived as a "superstition" and the church as the institution unmatched to current needs becoming obsolete. ${ }^{1}$

Another interesting thinker associated with this discourse was the Catholic priest and thinker Anton Kompánek (1891-1949), who represents its “idyllic" version, even more successfully [Nešpor 2008: 198]. In his book Slovák jeho povaha, vlastnosti a schopnosti (A Slovak - His Nature, Characteristics and Abilities) [Kompánek 1921] he shows the typical Slovak nature using rather wide-spread stereotypes of the time, linked to supposed national characteristics of Slovaks, among which he includes, e.g. modesty, industriousness, morals and piousness and uses these to eliminate emerging discords between Czechs and Slovaks based on the different natures of both nations [Tižik 2011: 40]. He views the different approach to religion and the role thereof in the life of an individual and nation as the elementary difference between Czech and Slovaks. ${ }^{2}$

It would certainly be possible to further analyze other specific ideal systems of Slovak intellectuals and political activists, which they used to shape their ideas of Slovak identity. For the purposes of this study, it is important that the above-mentioned Slovak thinkers formed an idea in various forms that was also important for the founders of the Slovak National Museum, more precisely, for one of the institutions that today constitutes the Slovak National Museum. This institution was the Slovak National Museum founded by Matica Slovenská in Martin, which from the beginning aimed to emphasize Slovak autonomy, originality and independence. ${ }^{3}$

When we take a closer look at their work, we find that their concept of Slovak identity and the Slovak nation is based on three interpretative axes. Axis one - us vs. them, where us, the Slovaks, are constantly endangered by power dominant societies, which try to impose their own culture and language (Hungarians) or value systems (Czechs) upon

1 A good analysis of Lajčiak's interpretation of the role of religion in Slovak society at the beginning of the twentieth century is presented by the sociologist Miroslav Tížik. For details, see [Tižik 2011: 40-42].

2 The role of religion, its study, and presentation in the process of creating Slovak national identity is described in more detail in my study Searching and Finding: A History of the Slovak Study of Religion [Václavík 2015: 55-86].

3 The Slovak historian Karol Hollý focuses on this issue. See e.g. [Hollý 2009] or [Hollý 2011]. 
us or deprive us of our peculiarity and authenticity. Axis two - low vs. high. The others usually represent the more powerful part of society. They are linked with cities, nobility, economic elites and so-called high culture. The truly "ours" can then be found in the countryside, in the nature and linked to the "unspoilt", i.e. authentic way of life lived by peasants and petty craftsmen. Axis three - countryside (nature) vs. cities, underlining and completing the previous axis. While the countryside is the place preserving the "origins" of Slovak identity, including for instance a strong bond with traditions and religion. Cities are the environment prone to the "corruption" of an original and genuine identity (e.g. by liberalism, linguistic plurality, cultural cosmopolitanism).

It is of interest that the ideas present in the concepts of the aforementioned thinkers have been significantly presented in the institution, which is both almost a literal embodiment and key legitimization of Sztompka's social iconosphere, i.e. the institution of the National Museum. The role of museums, especially the so-called national ones when shaping modern national identities, have been the focus of many foreign scholars for a long time [cf. for ex. Hooper-Greenhill 1992; Karp - Levine 1991; Kong 2005]. The most inspiring analyses include the work of Peggy Levitt Artifacts and Allegiances. How Museums Put the Nation and the World on Display [Levitt 2015]. The author analyzes history, the creation of collections and the modifications thereof in several museums of the world from New York to Singapore and observes to what extent museums reflect specific political concepts and historical ideas both of a nation as such (the museum as part of shaping the nation) and others (the museum as a tool for recognizing/controlling others). In her view, the museum is always a specific type of knowledge based on a specific set of values. The way individual artifacts are presented, collections drawn up and to what context individual exhibitions including permanent ones are set into is part of the process of legitimization of a specific social and political order, in which certain phenomena are privileged while others are marginalized and excluded [Levitt 2015: 7]. In this respect, museums are places, where one can see (in many cases even hear) the embodied ideas of specific groups and their position in the symbolic universe of specific societies. The author observes that in line with the "discursiveness of museums" the key role is played not only by the collections themselves and the drafting of these, but also the places where museums are located as well as the appearance of the buildings hosting museums.

All of this applies to Slovakia as well. In line with the way the role of a museum is analyzed by Levitt, I will attempt to interpret its importance in shaping national identity and the narrative linked to it and the modifications thereof at three levels. The first one concerns the museum as an institution, the second one the museum as a building and a symbol and the third one the museum as a space where the "story of one's own nation" is presented.

It should be said, however, that the application of this approach is not without problems in the case of the Slovak National Museum and can lead to some simplification. There are several reasons. First, it is its relatively complex history, associated with the complicated process of institutionalization. I will deal with these in more detail in the next chapter. Second, many of the permanent exhibitions that are important for our work (such as the collection of the ethnographic museum in Martin) were created during the Communist regime, and actually reflect its ideological concept of Slovak history and Slovak culture. Third, the Slovak National Museum has been transformed in the last few years, which 
also touches on the idea and scope of permanent collections. As a result, some of them are still "unfinished" (see the exhibition on Slovak history at Bratislava Castle). Fourth, the Slovak National Museum is currently comprised of more than forty institutions located throughout Slovakia. Much of it is dedicated to specific historical objects such as castles or other historical buildings. Some of them are devoted to national minorities living in Slovakia. This complicated structure makes the museum structure different from similar institutions in both Central Europe and other European countries [cf. for ex. Aronsson Elgenius 2011].

\section{The Slovak National Museum as an Institution}

Founding a national museum or an equivalent thereof is usually linked to the political ambitions of the founders. All the founding documents tend to determine that the main vocation of a museum is to preserve cultural heritage and develop learning, but at the same time, a newly founded institution shall present the maturity of one's own nation and support its political ambitions. The establishment of the British Museum in 1753 may be taken as an example. The founding of it was formally confirmed by the British parliament by a special act (The British Museum Act), which established the institution preserving the existing collections (e.g. Sloane's collection or the Harleian Library) and which differed in two principal characteristics from others. First, it was the first institution of its kind belonging formally to no individual (king, aristocrat, etc.) nor church, but was conceived as a national one from the very beginning. It was therefore freely accessible to all. This is in explicit conformity with the principal tendencies in British society after the so-called Glorious Revolution (1688), when the people-nation becomes the definitive political sovereign. The National Museum thus becomes one of the symbolic confirmations of the nation's sovereignty and political dominance. Another aspect is the fact that from the very start, it has been conceived as an institution of a "universal" shape. This means not as an institution focused on a single selected segment of human activity or of the surrounding world, as it was the case until then, and as illustrated by the affection of various cabinets of curiosities.

Similarly, additional such institutions began to be founded in other countries of Europe and, from the beginning of the nineteenth century, also in the Central European area. The most important for us is the founding of the Hungarian National Museum in Budapest in 1802 and that of the Patriotic Museum in Prague in 1818 (from 1854 the Museum of the Czech Kingdom, since 1922 the National Museum). The establishment of both institutions was also influenced greatly by political reasons. In the Hungarian case, the museum was officially founded by an act, similar to the British one, adopted by the Hungarian parliament upon an appeal by an important politician, Szechenyi, in 1807. It shortly afterwards became one of the key symbols of the modern Hungarian nation, which played a crucial role in the Hungarian revolution of $1848 .{ }^{4}$ The foundation of the Patriotic Museum in Prague was slightly different given the constitutional arrangement, since the constitutional

\footnotetext{
4 It was in front of the newly built National Museum that one of the leaders of the Hungarian revolution, Sándor Petöfi read the so-called 12 points, thereby determining the national and state sovereignty of Hungarians within the Austrian Empire.
} 
autonomy of the Czech Lands was greatly truncated following the Theresian-Josephine reforms. It was formally established on the basis of a "private" initiative of Czech political representation involving especially Czech nobility (House of Sternberg, House of Kolowrat), yet from the very start, it was considered a public institution. ${ }^{5}$

The history of the Slovak National Museum is still somewhat different and a bit more complicated. First, the origins of this institution and the first decades of its existence were closely related to Matica slovenská, the Slovak cultural heritage organization (1863), which, similarly to the equivalents thereof in other Slavic countries (Serbia, the Czech Lands), focused mainly on cultural and public education, while linked to a strong emancipatory, i.e. political dimension. ${ }^{6}$ This organization nevertheless dealt intensively with collecting activities focused principally on Slovak folklore [cf. for ex. Vlachovič 1979]. The activities of Matica slovenská were banned as hostile to the state by Hungarian authorities in 1875 , who rejected any Slovak emancipatory efforts. The activities were supplemented as of 1895 by the newly established Museum Society of Slovakia based, just as Matica slovenská before, in Martin. The newly established society also principally specialized in ethnographic and folklore collections, which were completed by historical and scientific objects. In 1908, the first building with permanent exhibitions was opened in Martin. The Museum Society ran the Martin museum up until 1961, when it was joined to the Slovak Homeland Museum in Bratislava.

It is of interest, however, that the museum founded by Matica Slovenska was not the only one, not even the oldest museum, which explicitly devoted itself to the territory and history of today's Slovakia. In 1872, the Museum of Upper Hungary was founded in Košice, but it was closely connected with the Hungarian political representation. It aimed to support the emerging Hungarian nationalism while confirming Hungary's historical and political indivisibility in all its historical areas. In a sense, the activities of this museum were a sort of ideological antipode of the activities associated with Matica slovenská, which in turn emphasized the identity of Slovaks and their culture. It is, therefore, not surprising that the Museum of Upper Hungary was generously supported by the state and became part of the formal educational and cultural structures of the Hungarian state [for more see Mruškovič - Darulová - Kollár 2005: 48n].

After 1918, when Slovakia became part of the newly established Czechoslovakia, a new institution was set up. It was the Slovak Homeland Museum in Bratislava founded in 1924 as the Slovak National Geographic and Historical Museum supported by the Slovak National Geographic and Historical Museum Society. An essential role in its establishment was played by personages such as Dušan Jurkovič (originally a Slovak architect who worked mainly in the Czech Lands) or Václav Chaloupecký (originally a Czech historian who founded Slovak historical science after 1918). They wanted to establish a museum that would meet several primary goals. First, it was to be a modern scientific institution that would be comparable to similar museums in the region. Second it would be, unlike

5 Formally, the museum was established by the Society of the Patriotic Museum in Bohemia, which lasted until 1934, when the museum was transferred under the Czech Land Authority (one of the self-governing bodies under the 1st Czechoslovak Republic). In 1949, the museum was taken over by the Czechoslovak state. State bodies contributed to the funding of the museum to a large extent. The principal building on Wenceslas Square, built in 1885 to 1891, was funded by the Czech Land Assembly as the official body of the Czech Kingdom.

6 On the history of Matica slovenská, see [Winkler - Eliáš 2003]. 
the Slovak National Museum in Martin, ideologically associated with the newly established Czechoslovakia.

As of the second half of the 1920s, there were two museums in Slovakia, aspiring for the leading position in a territory that could barely support one of them. The museum in Martin referred to its tradition, number of supporters and the promotion of Slovak national interests. The fixation on ethnography grew even stronger, because the museum in Bratislava had taken over all the other fields of research. The Slovak Homeland Museum in Bratislava had a more favorable position in the eyes of the ruling political elites. Other advantages were the scientific background; the position in the center of Slovak cultural and intellectual life, the broader orientation of its activities and the additional finances. It was rooted in the urban, liberal milieu and prepared support for the actual state idea [Hudek 2011: 837].

In 1934, the Slovak Museum of Agriculture established in 1924 was associated with the Slovak National Geographic and Historical Museum. Originally founded as an affiliated branch of the Czechoslovak Museum of Agriculture in Prague, the main building thereof became that of the Slovak National Museum. As of 1940, this joined museum has born the official name of the Slovak Museum.

The aforementioned brief history of creating the Slovak National Museum demonstrates the wide range of specifics concerning this institution. First of all, as opposed to national museums of nations with an established state tradition, the Slovak National Museum was not connected all that long with official state institutions. It expressed more of a cultural autonomy than a political one and was supposed to demonstrate that Slovaks are not merely a cultural "rarity" within a constitutional Hungarian and subsequently so-called Czechoslovak nation, but a full-valued ethnic group with its own habits, traditions, developed culture and rich history. This did not change even after the creation of an independent Czechoslovakia in 1918, when the Slovak National Museum in Martin was not transformed into an official institution connected with the new state and the official structures thereof, but maintained its institutional autonomy and was subsequently able to oppose the official concept of so-called Czechoslovakism, which questioned the full independence of the Slovak nation.

Second, it was symbolic that the seat of the museum and the society, which ran it, was maintained in Martin and was not transferred to the new capital city of Slovakia, Bratislava. The first attempt to establish an official museum institution linked to state structures did not take place until the creation of the so-called Slovak State (Slovenský štát), ${ }^{7}$ which basically transformed regional and topical museums (see above) into a new institution called the Slovak Museum. This was meant to fulfill "constitutional" goals and the declared ambitions of the new state. These were, in particular, the strengthening of "Slovak patriotism and the national spirit", in full accordance with the ideology of a nationalist and authoritatively established Slovak Republic [see for ex. Palárik 2008]. Among other things,

\footnotetext{
The term Slovak state is used mainly in traditional Czech and Slovak historiography. Officially, this state unit was only called the Slovak state for several months - from its announcement on 14 March until 21 July 1939. By adopting Constitutional Act No. 185/1939 On the Constitution of the Slovak Republic, the official name of the state was changed to the Slovak Republic. This name was then valid until the end of the independent Slovak state in 1945.
} 
it was very much defined against the liberalism of the so-called First Czechoslovak Republic, as well as the idea of so-called Czechoslovakism.

It is remarkable that the Slovak cleric-fascist regime of the so-called Slovak State did not include the original museum in Martin in the newly established institution, still respecting its autonomy. The main reason was probably that there was not enough time or resources for a reorganization of the museum's system because the Slovak state only existed for six years (1939-1945) and most of the time had to be focused on other priority issues. As already mentioned, this was eliminated by the communist regime, which combined both institutions after years of efforts establishing the Slovak National Museum based in Bratislava. The legal framework for the merger of the two institutions was created by the Act of the Slovak National Council No. 109/1961 on Museums and Galleries, adopted in 1961. The original museum of the Museum Society in Martin was turned into the Ethnographic Museum, i.e. a specialized branch.

Third, in spite of the final institutional combination of the museums in Martin and Bratislava, it was the museum in Martin, which maintained the characteristics of the national museum for the long time to come, since Bratislava primarily hosted natural science collections and also officially the historical part of the museum, which began to operate in the newly restored Bratislava castle, the characteristics of which still have a rather awkward effect.

The Slovak researcher Adam Hudek consequently mentions a quite interesting observation in connection with the above-mentioned: "None of the two Slovak museums had, or would have, the status and influence of national museums in neighboring countries. The impact of the Slovak museums, on the formation of the national narrative and national identity building, was only marginal. The Czechoslovak state, otherwise highly active in the propagation of its state idea in schools and cultural activities, did not use the potential of museums as possible nation-building tools. They were still viewed as private enterprises and they did not try to gain control over their activities" [Palárik 2008: 837]. ${ }^{8}$

Other significant modifications, from the institutional perspective, were brought about by the creation of the independent Slovak Republic in 1993, when other branches of the Slovak National Museum were founded focused on the history and culture of different ethnic and religious groups living in Slovakia. This thereby abandons the original and traditionally patriotic aspect and moves it to the other extremity of the axis described by Peggy Levitt, dealing with modifications of current national museums, as the axis between the particular nationalism and universal cosmopolitanism [Levitt 2015: 136-138]. This helps uncover a new discursive paradigm, which reveals Slovakia as a cultural and historical crossroads and which progressively pushes away the original paradigm of Slovakia as a landscape combining the geographic specifics and the originality and independence of Slovaks and their culture. This shift is manifested, as shown below, in modifications of the principal collections, particularly scientific and historical ones.

The original "Martin" museum still retains, however, the traditional symbolic discourse on Slovak identity as described above, and in many respects corresponds to the concept of Slovak intellectuals of the late nineteenth and early twentieth centuries, such as Svätozar

8 The historian Jozef Vlachovič also comes to similar conclusions. See [Vlachovič 1979: 204]. 
Hurban Vajanský. In this context, it is interesting to note that in Martin, which is still considered a kind of spiritual capital of Slovakia for many traditional Slovaks, another branch of the Slovak National Museum was created after the merger of one Slovak National Museum, Two of these are of the most interest for the present task. These are the Martin Benko Museum (founded in 1973) and the Karel Plicka Museum (1988). Both were considered the most renowned artists of the twentieth century associated with Slovakia, its culture and identity. While Benka was an expressionist-influenced painter from Slovakia, Karol Plicka was a Czech photographer and filmmaker who devoted a significant part of his work to Slovakia and is much better known here than in his homeland. What is interesting, however, is that both authors "materialize" the concept of Slovak identity in their works, which corresponds to the "traditionalist" emphasis on the "spirit of the nation", which is mainly embodied in folk culture. It seems to correspond not only to the romantic nationalism of the early twentieth century but also, as we will later show, to some of the ideas of the communist regime.

\section{The Museum as a Symbol and a Building}

Many national museums are perceived principally by means of buildings, which are usually not only a space to host collections and hold exhibitions, but also important national symbols expressing national aspirations and expectations. The main buildings of national museums are thus among the most luxurious secular buildings and are often located at symbolically significant places (close to a political center, at a key public location such as for instance a central square, etc.) and are usually well visible and symbolically prominent. It is not unusual for them to be in places, where important historic events take place (declaration of independence, large manifestations of historic relevance, etc.). This is true of most national museums in our geographical area - from Prague to Vienna and Budapest. In all of these cities, buildings of national museums or their equivalents are located in places of symbolic significance, they are representative or even overwhelming and are related to many important political events of the past century and a half, when modern nations were finally formed. The components of some, e.g. the National Museum in Prague, are also symbolic pantheons of the most important figures of the given nation, reflecting various political conceptualizations of modern history. This also makes the national museum the sacred places of given nations, since they combine symbolic and real history, with such a combination becoming part of the interpretative key to one's own history and the inherent concept of one's own identity.

The example of the Slovak National Museum is another peculiar exception, which seems to point out the role of "small history" in shaping the Slovak identity. The principal buildings of the Slovak National Museum in Bratislava were not used as representational museum buildings known from neighboring Central European countries. The main building hosting the institution's management and holding the natural science collections, was originally the Bratislava branch of the Museum of Agriculture in Prague. It was built in 1925 to 1927 by the architect Milan Michal Harminc. The building is somewhat conservative, and its features reflect the effort to be as purposeful as possible. The same austerity is true of the sculptural decoration by František Úprka, representative of the folklore Art Nouveau movement. 
The Czech historian Jan Rychlík points out an interesting fact in connection with the museum building. Its construction was significantly supported by the state budget, mainly thanks to the Slovak politician Milan Hodža. He was a prominent politician of the Agrarian Party at the time of the so-called First Czechoslovak Republic, which was the dominant political party. The museum building was supposed to express this party's ideology. The ideology of this party considered the crucial social and political layer of Czechoslovak society to be farmers, and at the same time, it was closely linked to the idea of a unified and independent Czechoslovakia [Rychlik 2010: 208]. In other words, today's main building of the Slovak national museum was not conceived as a representative building expressing the ambition or self-concept of the Slovak nation, but should have expressed a political ideology.

Another building in Bratislava, currently linked to the Slovak National Museum, is the Bratislava Castle. ${ }^{9}$ In contrast to Harminc's building, this is a prominent and symbolic building, which has only recently become part of the museum. At the beginning of the nineteenth century, the castle burnt down and was in ruins. After 1918, long debates concerning its further fate and possible use began, culminating in the 1950s with a decision to restore the ruined compound and use it partially for the purposes of the museum, which became very relevant after 1961 (see above). Other than that, the castle was also used for ceremonial purposes and several institutions are still hosted here today. Apart from the Slovak National Museum, these are for instance the Slovak National Council (parliament). Leaving aside the fact that the Bratislava Castle has been continuously searching for its place, ${ }^{10}$ its unambiguous and strong link to the museum is only felt by very few. It could be argued that the building of the castle is not identified with the national museum, but is rather deemed to be a space hosting the museum.

It should also be said that while the Bratislava Castle has been perceived as a strong symbol in former decades, it still lags behind other traditional symbols, dominated by the Tatra Mountains or symbols linked to religion (mainly the Slovak double cross). As concerns historical buildings, Devín tends to outrival it [for more details, cf. for ex. Tížik 2011: 308nn]. The Bratislava Castle is still understood as an important symbol of Slovak statehood, which has been firmly integrated in the discursive map of modern-era Slovak history and the interpretation thereof. This transformation of a ruin, which was supposed to be torn down during the first independent Slovak state in the 1940s, according to all the proposals, into one of the key symbols of an independent Slovakia, is well illustrated both by the historic events for which it was chosen (signing the constitutional act concerning the creation of the Czechoslovak Federation in 1968, the ceremonial signing of the Slovak Constitution in 1992 or the inauguration of the first president of the independent Slovak Republic in March 1993) and by the erecting of a monument dedicated to the ruler of the Great Moravian Empire, Svätopluk, who is presented here as the "King of Ancient Slovaks".11

9 On the history of the Bratislava castle, see for example [Gažo - Holčík - Zinser 2003].

10 After the creation of the independent Slovak Republic, there were some very intense debates concerning the use of the compound in the early 1990s. Apart from the function of the museum, other possibilities were considered - e.g. the seat of the President of Slovakia or refurbishing the entire compound to house the Slovak parliament.

11 The creation of the monument, see below, sparked great controversies in the Slovak public space and was considered principally a political matter from the very start. Apart from numerous protests concerning the form of the monument as such, the most frequent questions focused on the location (Svätopluk had 
The oldest buildings relating directly to the Slovak National Museum are not located in Bratislava, but in the several times mentioned town of Martin. It was considered the center of the Slovak national movement and the spiritual center of Slovaks at the turn of the twentieth century. ${ }^{12}$ The original building of the museum was built in 1907 by arch. Milan Michal Harminc, who designed the building in Bratislava some 20 years later, now housing the museum management. The building was built using a nation-wide collection and thanks to the activity of the catholic priest Andrej Kmet', after whom it is called today. It is a rather unpretentious classicist building, yet within the small-town Martin environment it must have had a representative effect. Obviously, it may not have compared to similar buildings raised in neighboring countries as far as size and imposing architecture are concerned. This was caused by the fact that the other buildings were usually greatly funded from public sources and, as has been already said, reflected the political and power ambitions of the individual nations. At the beginning of the twentieth century, however, Slovaks were under immense pressure from the politically dominant Hungarians, who were very spiteful regarding any attempt at political emancipation and would repress any display thereof, even symbolic ones.

Even in terms of size, the original building is rather small (less than $800 \mathrm{~m}^{2}$ ), which is why, shortly after the change in the political situation and the creation of the independent Czechoslovak Republic, ideas to build a new, larger building began to appear. The design was once again the work of the architect Milan Michal Harminc. The new, much larger building $\left(46,000 \mathrm{~m}^{2}\right)$ was inaugurated in 1932 and contrary to the original historicist classicist building reflects a modernist style influenced by Functionalism. The building is clearly dominant, which is even emphasized by the fact that it is built on the axis of the principal street of Martin leading from the principal square. It expresses in a symbolic manner the ambitions of the Slovak nation.

\section{The Museum as a Space to Construct One's Own Identity and History}

Museum expositions, especially the so-called permanent exhibitions, are an integral part of the prevailing and generally accepted narratives concerning one's own identity. This fact is usually accepted in relation to presenting the history or culture of a given nation. In a way, this can apply to other collections, e.g. scientific ones. This is especially true in cases, when nature, mainly the local one, is considered an integral part of the national identity, which is certainly the case of Slovakia. The following analysis will therefore focus both on historical collections and the presentation thereof of collections dealing with the definition of "cultural" identity, as well as the scientific collection. Given the complicated structure

no demonstrable link to Bratislava or Bratislava Castle) or the ahistoric appellation of Svätopluk as a king. Similarly, part of the liberal opposition criticized the fact that Svätopluk was proclaimed "King of the Slovaks", while there is no historical evidence.

12 At the beginning of the twentieth century, Bratislava was considered to be more of a German or Hungarian town. When Czechoslovakia was founded in 1918, 42\% of Bratislava inhabitants declared German nationality, $40 \%$ Hungarian and only $15 \%$ Slovak. Even the name Bratislava as such is quite recent, being used officially since 1919 only. Until then, Bratislava was called Poszony (Hungarian) or Pressburg (German), whence comes the ancient Czech name Prešpurk or the Slovak appellation Prešporok used until 1919. For modifications of ethic and cultural identity of Bratislava in the last two centuries, see [Salner 2001]. 
of the Slovak National Museum and its partial collections, we will primarily focus on the collections located in Bratislava and Martin, as these are key to our purpose (see above).

The historical exposition of the Slovak National Museum is housed in the principal building of the Bratislava Castle. As was noted in the preceding part, it has to be understood within the context of the location as a way to express the concept of Slovak history culminating with the "renewal" of the Slovak state. The very entrance to the palace hosting the museum is linked to that concept and interpretation of Slovak history. Every visitor has to pass round the statue of Prince Svätopluk. At the time of the unveiling of the pedestal, the inscription read "King Svätopluk - King of the Ancient Slovaks". This inscription was removed later following large criticism from both the general public and scholars. The reason was that Svätopluk was never a king (or there is no evidence thereto) and presenting him as the ruler of the first Slovak state is genuinely ahistoric. At present, the pedestal contains the name of Svätopluk and the dates of his birth and death as well as a quote from the Papal bull of John VIII, calling Prince Svätopluk a devote and genuine Christian. In this way and as part of the social iconosphere, the statue confirms the remarks of many Slovak authors, for instance Andrej Findor quoted above, that Great Moravia is presented as the first of the apices of Slovak history and the imaginary golden era. It is vital to note that the reference to Great Moravia as a golden era is linked to the reference to religion as its key component, confirming thus the concept of Christianity as the cornerstone of national identity. The "dispute" over "King" Svätopluk also demonstrates how closely the historical and political level of the interpretation of Slovak identity and the associated Slovak history is intertwined. They can be separated from one another in the framework of academic debate (most Slovak historians rejected the simplified understanding of Svätopluk as the first Slovak ruler), but they are almost inseparable in public discourse.

The permanent historical exposition itself is of a similar nature, although it has been fragmented in its form for several years already. Only the first part is finished, presenting the most ancient history up to Great Moravia perceived again as the first apex of Slovak history and as its "breaking point". The exposition is rather small and covers only part of the last floor of the castle palace. It is nevertheless quite eloquent. The exhibits from the ancient era, mainly those relating to Celtic or Germanic settlements and contacts with the Roman Empire, are meant to emphasize the fact that the territory of today's Slovakia has always been part of (and thus heir to) important European cultures as well as a place where such cultures met, permeated and enriched each other, which corresponds to the way the Slovak National Museum presents today's Slovakia on the "institutional level" as a place where different ethnics and cultures meet and live next to one another. ${ }^{13}$ The entire exhibition culminates with the part devoted to Great Moravia, which is remarkable mainly by the attention paid to the fact that it was not only the first Slavic state in the territory of today's Slovakia but also by stressing its Christian characteristics. In other words, what the visitor is "prepared" for upon entering the museum, is confirmed by the exhibition itself.

This concept is not and was not accepted without problems. Many prominent representatives of the Slovak National Museum, such as its former director Peter Maráky, have

13 The Slovak National Museum includes specialized museums focused on prominent ethnic and cultural minorities living in Slovakia. Apart from Hungarians and Czechs, Jews, Roma, Croatians, Ukrainians and Ruthenians also have "their own" museums. 
strictly rejected it [Hudek 2011: 839]. Given that the new permanent exhibition was created at a time when nationalist forces played a significant role in the Slovak government, it is quite understandable that it is based on the concept described above.

Concerning the permanent exhibitions of the historical collections, ${ }^{14}$ another fact is deserving of mention. For over 250 years, Bratislava was the crown city of the Hungarian Kingdom and the crown of St. Stephen was deposited at the Bratislava Castle. These facts are presented in one of the permanent exhibitions, the part of which is a copy of the crown of St. Stephen, although the entire exhibition is quite minimalist and quite played down, so visitors might have problems finding it at all.

The second specific set of collections relating directly to issues of Slovak identity are the ethnograph and folklorist collections in Martin. They primarily focus on the traditional Slovak countryside and folklore. Focusing on these areas has been typical of the "Martin" Museum since its founding at the end of the nineteenth century. It reflects a particular type of discussion associated with the ahistorical construction of national identity, the author of which was an important Slovak thinker and political leader Svätozár Hurban Vajanský (1847-1916). Vajanský was convinced that to understand what a "nation" was, there was a need to study its spirit, which he associated with folk culture. That is why he organized the work of the museum to be focused primarily on collecting ethnographic material about Slovak people, which was the only carrier of the Slovak national spirit. The museum and its collections should have served the nation's building purpose as evidence of the existence of the Slovak nation in Hungary. The institution should have been based on pure ethnography - and the science of even the smallest and most lonely nation and the representatives of society [Hudek 2011: 835].

The concept of the permanent exhibition was created 40 years ago and reflects the notion that the core of Slovak culture lies in the countryside. ${ }^{15}$ In principle, it reflects the Marxist-Leninist concept that "folk" has always been the most influential "creator" of history and culture. Folk culture is therefore considered to be at the heart of national culture in this context. Otherwise expressed, it is its most authentic expression. It should be noted, however, that at this point the essential ideological basis of the "communist concept" of the permanent ethnographic collection coincides with the views of the founders of the Slovak National Museum, especially the above-mentioned Svätozár Hurban Vajanský. This may give the impression of a sort of "continuous interpretation" of Slovak identity. It would be a mistake to succumb, however, to this impression. Despite some similarities, the motivations of the "founding fathers" of the Slovak National Museum and the communist ideologues were different, and this must be kept in mind. Thus, while the current ethnological collection of the Slovak National Museum is basically a statement of the communist concept of the nation and its culture, it contains some interesting ideas that have a broader impact.

14 Apart from a survey exhibition, or the first part thereof devoted to Slovak history, the permanent exhibitions at the Bratislava Castle include exhibitions concerning the castle itself, especially the history and reconstruction. The most recent of such exhibitions concerns the Celtic settlements in the castle area and the agglomeration of Bratislava in a larger view, which is based on numerous archaeological findings uncovered during the castle reconstruction.

15 Cf. for example, the official website presentation of the exhibition. See <http://www.snm.sk /? etnograficke-muzeum-stale-expozicie\&clanok=narodopisna-expozicia $>$. 
The exhibition begins with a reference to the first Slavic inhabitants and goes to great lengths to depict the countryside as the authentic Slovak space in opposition to the "foreign" town (in general Hungarian or German ones). The simplicity of the countryside is emphasized and presented principally as a virtue. The contact with nature is also predominant here, not only with its "cultural" form (one part of the exhibition is called Mankind and Soil) but also with its "wild", original kind. In this respect, what is remarkable is the fact that those parts of the exhibition dealing with use of various materials, stress in particular so-called natural materials (wood, earth, stone, straw, etc.), while "civilizational" materials (metal) are presented as precious and specific items. This complies of course with the fact that in the country, those materials were expensive and rare, but it also confirms the concept of "the unity of the countryside and nature".

Similarly, remarkable is that an important space is once again dedicated to the role of religion as a component of identity. Although the "normalization" concept of the 1970s tends to stress the heterogeneity of institutional (church religiosity) especially compared to the simplicity of rural life, the role of so-called popular religiosity is presented on several levels. This is either by means of exhibits such as for instance pictures of saints or by other daily used religious artifacts, and also by exhibits related to the natural life cycles, where religion played a crucial role. This can be seen as reflecting Benka's and Plicka's topics, where rural religiosity plays an important role (next to the presence of religious symbols such as crosses or pictures of the saints in many of their pictures and photographs rural churches become topics as well). Finally, it is worth mentioning that in contrast to the current historical exhibition the ethnographic one is much larger and more impressive.

\section{Conclusions}

Returning back to questions asked at the beginning of this study, one can state that even the current presentation of Slovak identity within the National Museum, in spite of certain shifts towards universalism, tends to reflect the way it is presented in other important artifacts of the social iconosphere (banknotes, stamps, textbooks, monuments, etc.). They still elaborate the image of Slovakia as the "country under the Tatra Mountains" (sacralization of nature) growing from the Great Moravian heritage, which it develops further (the role of Christianity) and which is an eminent crossroads of cultures (a universalist reference). The Slovak identity is also considered the identity of a nation/society, which has maintained its originality and authenticity despite adverse fate and the pressures of stronger neighbors (Hungarians, Czechs, Germans), in particular thanks to the rural element.

There is a need to state unequivocally, however, that when interpreting the role of the National Museum in the process of creation and presentation of national identity, the following facts need to be considered. First, the history of the unified Slovak National Museum is very short (less than sixty years). Almost half of its history falls within the period of the Communist regime, which closely controlled the "ideological aspect" of museum activities and subordinated it to the Marxist-Leninist ideology. The second half of its existence is then marked by "searching for itself", which was mostly somewhat indirectly influenced by political twists in contemporary Slovak society (so-called Mečiarism, a pro-European turn in the millennium, the dominance of populist and nationally oriented parties in the last decade). 
Second, the historical "double track" is even evident in the current activities and form of the Slovak National Museum. The two central institutions, which have made up the Slovak National Museum since 1961, have been created for a different purpose, differentiated by the ideological milieu and based on various political and intellectual structures. Although the communist regime tried to eliminate these differences by a common ideological focus, it was not very successful. The permanent historical collection, created during the communist regime and reflecting the Marxist-Leninist ideology, was abolished in this form and gradually replaced by a new one in the last twenty years. This fact is quite understandable because, according to available information, it was conceived strictly ideologically and underlined both the Marxist-Leninist concept of history and the important role of Czechoslovakia. ${ }^{16}$ Its further existence was in complete contradiction with the museum's mission after 1993. The second significant permanent exhibition, the ethnographic collection, exists in the form it was acquired in the mid-1970s, i.e., at the time of so-called normalization. The question is why. One of the answers may be the lack of financial resources that the Slovak National Museum has been struggling with for a long time and which is exacerbated by its complex structure and broad scope of activities. I personally believe that one of the reasons is that the "normalization" concept of the ethnological collection is in some respects close to the traditionalist concept of Slovak national identity, for example, by emphasizing the role of the "people" or interpreting folk culture as an authentic national culture. Although the Communist interpretation of these phenomena came from other sources and pursued other goals, in some conclusions, it was "intersected" with the concept on which the Slovak National Museum was founded by intellectuals closely connected with Matica slovenská.

Finally, a specific example of Slovakia demonstrates that some broader theoretical concepts, such as the P. Levitt concept, cannot be transferred to any environment without significant modifications. The history of the institutionalization of a concrete national museum can often tell us more than the existing permanent collections.

\section{Bibliography}

Aronsson, Peter - Elgenius, Gabriella (eds.) [2011]. Building National Museums in Europe 1750-2010. Linköping: Linköping University Electronic Press.

Bellah, Robert [1967]. Civil Religion in America. Deadalus 96 (1): 1-21.

Bellah, Robert [1975]. The Broken Covenant: American Civil Religion in Times of Trial. New York: Seabury. Francisci, Ján [1845]. Slovenske povesti. Levoča.

Gažo, Mikuláš - Holč́k, Štefan - Zinser, Otto [2003]. Bratislava pred sto rokmi a dnes. Bratislava: Vydavatelstvo PT.

16 In all probability the most compact description of the permanent collections of the Slovak National Museum is the study of Lubomír Lipták [1990] Múzeá a historiografia na Slovensku po roku 1945. Liptak points out that the exhibition, whose concept was created in 1955, followed two main lines of thought. The first was the "universalist concept" of history in Marxist interpretation, according to which the history of humankind is ruled by the mass of ordinary people, and not by the elite. The second is the "construction" of Slovak history as history, which is represented by an independent and culturally autonomous Slovak nation that has lived in the territory of present-day Slovakia since the early Middle Ages. While the Hungarian state, which included Slovakia for almost a thousand years, was portrayed as an "oppressor", coexistence with the other dominant nation, the Czechs, was described by the ruling ideology as fraternal. Any clashes and conflicts were then interpreted as a consequence of class conflicts, which were removed by the establishment of a socialist state. 
Hollý, Karol [2009 ]. Formovania historickej pamäti o Muzeálnej slovenskej spoločnosti do roku 1914 ako ideový konflikt "všeobecnej" a "národnej” vedy. In. Z dejín vied a techniky na Slovensku. Bratislava: Spoločnosṫ dejiny vedy a techniky.

Hollý, Karol [2011]. Memorandum národa slovenského ako historiografický prameň. In. Pekarovičová, J. Vojtech, M. - Španová, E. (eds). Studia Academica Slovaca 40. Prednášky XLVII. letnej školy slovenského jazyka a kultúry. Bratislava: Univerzita Komenského, pp. 101-114.

Hooper-Greenhill, Eileen [1992]. Museums and the Shaping to Knowledge. London: Routledge.

Hudek, Adam [2011]. National Museums in Slovakia: Nation Building Strategies in a Frequently Changing Environment. In. Aronsson, Peter - Elgenius, Gabriella (eds.). Building National Museums in Europe 1750-2010. Linköping: Linköping University Electronic Press, pp. 817-846.

Karp, Ivan - Levine, Steven (eds.) [1991]. Exhibiting Cultures. The Poetics and Politics of Museum Display. Washington: Smithsonian Institutions Press.

Kompánek, Anton [1921. Slovák, jeho povaha, vlastnosti a schopnosti. Prague: published at own expenses.

Kong, Lily [2005]. Representing the Religious: Nation, Community and Identity in Museums. Social and Cultural Geography 6 (4): 21-48.

Lajčiak, Ján [1920]. Slovensko a kultúra. Myjava: Slovenská evengelická theologická akadémia.

Levitt, Peggy [2015]. Artifacts and Allegiances. How Museums Put the Nation and the World on Display. Los Angeles: University of California Press.

Lipták, Lubomír [1990]. Múzeá a historiografia na Slovensku po roku 1945. Zborník Slovenského národného múzea - História 30, pp. 245-258.

Miháliková, Silvia [2005]. Political Symbolism of Slovakia: Between the Cross and European Star. Slovak Sociological Review 37 (6): 529-554.

Mruškovič, Štefan - Darulová, Jolana - Kollár, Štefan [2005]. Muzejníctvo, muzeológia a kultúrne dedičstvo. Banská Bystrica: Univerzita Mateja Bela.

Nešpor, Zdeněk R. [2008]. Ne/náboženské naděje intelektuálů. Vývoj české sociologie náboženství. Prague: Scriptorium.

Palárik, Miroslav [2008]. Múzejníctvo v Slovenskom štáte. Studia Historica Nitriensia 14: 295-313.

Pauza, Miroslav - Hajka, Dalimír (eds.) [1989]. Antologie z dějin českého a slovenského filosofického myšlení. Od roku 1848 do roku 1948. Prague: Svoboda.

Rychlík, Jan [2010]. Zemědělská muzea v Československu. In. Harna, Josef - Rašticová, Blanka (eds.). Agrární strana a její zájmové, družstevní a peněžní organizace. Uherské Hradiště: Slovácke muzeum, pp. 205-213.

Salner, Peter [2001]. Ethnic Polarisation in an Ethnically Homogenous Town. Czech Sociological Review 9 (2): 235-246.

Shapiro, Lawrence [2011]. Embodied Cognition. New York: Routledge.

Sztompka, Piotr [2007]. Vizuální sociologie. Fotografie jako výzkumná metoda. Prague: Sociologické nakladatelství.

Tížik, Miroslav [2011]. Náboženstvo vo verejnom živote na Slovensku. Bratislava: Sociologický ústav SAV.

Václavík, David [2015]. Searching and Finding: A History of the Slovak Study of Religion. In. Bubík, Tomáš - Hoffmann, Henryk (eds.). Studying Religions with the Iron Curtain Closed and Opened. Leiden: Brill, pp. 55-86.

Villanova, Gabriela - Kowalská, Eva - Krekovičová, Eva (eds.) [2009]. My a tí druhí v modernej spoločnosti. Konštrukcie a transformácie kolektívnych identít. Bratislava: Veda.

Vlachovič, Jozef [1979]. Die Museen in der Entwicklung der Slowakischen Nationalkultur. Studia Historica Slovaca 9: 187-233.

Winkler, Tomáš - Eliáś, Michal, et al. [2003]. Matica slovenská: dejiny a prítomnost. Martin: Matica slovenská.

David Václavík is Associate Professor at the Institute of Religious Studies in Masaryk University in Brno, where he completed his doctoral studies and habilitation as well. He focuses on the role of religion in modern society and its changes. He has published several studies and publications on this subject, including several monographs, the most important of which are 
the Religions and Modern Czech Society and Sociology of New Religious Movements. He has also been involved in several international and national research projects, such as Religion and Values in Central and Eastern Europe and Detradionalization of Religion in the Czech Republic. Nowadays, he is increasingly engaged in such issues as the relationship between politics and religion or study of atheism and non-religion. 